\title{
Aspects of Cultural Utopia Displayed Through Anarchy in the Characters of Ulysses
}

\author{
PhD. Dalila Karakaçi
}

"Luigj Gurakuqi” University, Shkoder, Albania; Email:karakacidalila@yahoo.com

\author{
Doi:10.5901/ajis.2015.v4n3s1p317
}

\begin{abstract}
This paper will be focused on an investigation in the expansion of cultural utopia through an invading anarchy in some characters of Ulysses. In the 18th and 19th century is widely perceived a new anarchy and utopia, different from that of religious connotation. In many utopian ideas, with anarchist connotation, is expressed the belief of creating a despotism, which lately will disappear to leave the place to a country avoiding class division, leading to the transformation of the individual. At the beginning supportive of Irish Renaissance, but shortly very critical, Joyce attempts to epitomize the spiritual emptiness linked to Irish Catholicism together with the absentee of ideas from its leaders in the independence movement of Ireland. In all his works prevail the perception that imperialism is sustained by a Catholicism that plays the role of a camouflaged European nationalism. Many controversies are the basis of Illuminist inspiration in the 19th century. Supposed to be the source of a changing society, they embraced much exclusion, starting from the fact that it was not taken into consideration the difficult situation of slaves, women, prohibited religions etc. Through an empirical analysis of some characters in Ulysses, I will arrive to the point to evaluate these ideas that perturb the characters of Ulysses, and above all Joyce himself, abound in the episodes of Ithaca, Nestor, Cyclopes, Thelemacus
\end{abstract}

Keywords: cultural utopia, anarchy, Ulysses, Joyce, imperialism

\section{Introduction}

If we horizontally and vertically analyze the ideas of utopia developed during the years and centuries, it is clearly understood a transformation, as they become part of the structure of life and contemporary experience. Manheim (1985) describes utopia as "a sort of passing orientation of the reality that at the same time rips the connections with that existing reality." (p.173) At the core of different concepts on utopia, which prevailed in the western societies, was the ideal creation of a society. This concept varies from the search for reflection over a better life, but it can even change to a pursue of impressions not based on reality, being just an immeasurable project of human mind. The meaning itself of the word utopia, of Greek origin, can be translated as eu-topia (Manheim, 1985, 173), a place finding happiness or as outopia, a place not based on reality, but a result of fantasy. Different supporters of utopia, such as Saint Thomas, Fourier and Owen had no intention to emancipate the specific classes, but humanity as a whole (Davis, 1984, 4). While Thomas Moore in his book Utopia (1516), projects utopia as a way of thinking for different kinds of societies, maintains the notion of Manheim that a good living can be reached only outside the existing reality.

\section{Anarchy in the Utopian Context}

A new anarchy and utopia, different from that of religious connotation, is widely seen in the $18^{\text {th }}$ and $19^{\text {th }}$ century. An example of secular anarchy is found in the ideas of the philosopher William Godwin (1756-1836), who expressed himself against wars, unconditioned dominance of whatever demagogue, believing that only education and liberty would bring forward salvation. In Robert Owen (1771-1858) we find the same way of society salvation from educational and economic organization. He further explores this notion, being persuaded by his socialist connections, and perceives the salvation of the society within the social cooperation, overruled by the faith that man origin is not in the sin, but in the improper governance system. Pier Joseph Proudhon (1809-1865), a French philosopher, envisions the salvation of society in the humanist mutual aid within society. Contrary to his precursors, he asks for an over passing of the capitalist system and the establishment of a society without classes, where the formation of nation federations will bring the desired peace. Another philosopher, ranked against the economic and political system of his era is Henry de Saint Simon (1760-1825). He insinuates the idea of a European union, within the political and economical arrangement, as a manner to disappear the conflicts within states; in the meantime the Industrial Revolution would have another helpful approach in the war 
against poverty. Of matching vision is even August Comte (1798-1857)), who intended to obliterate the conflicts within states, and manage the development of technology in favor of humanity.

Contrary to his predecessors, Hegel (1770-1831), the German philosopher, thought that the historical processes were not based on a continuum repetition, but occurred as simple developing progressions. His theoretical point of view on history replaced faith, wide spreading the contemplation that the divinity concept on earth was represented by the state. Every nation or civilization has its period of blooming, as a result is repudiated the intervention of other nations and countries in this period of superiority. The impression of this world and history advancing from the dialectic of thesis, synthesis and anti thesis was encouraged by Engels and Marx. As a result of the Industrial Revolution, Engels and Marx believed that at the heart of the historical advancements was the economic contradiction within the society classes. Marx defended the complaining of the poor lower classes seeking a happy ending through the distribution of the material goods. The state will react through obtaining the means of production from the capitalist class, building the real communist system of dictatorship, making the individuals more human in a society without classes. This is a typical utopian idea, with anarchist connotation, expressing the vision of building a dictatorship, which will later disappear leaving the place to a society without classes and to a better individual human transformation.

\section{Cultural Utopia as Anarchy in the Characters of Ulysses}

The displacement of a culture taking the form of an invading anarchy is widely observed in many episodes of Ulysses. A literature movement as Irish Renaissance tried to found the inspiration in the roots of the country tradition. Supportive at the beginning, but very critical later, Joyce tries to demonstrate the spiritual emptiness of Irish Catholicism and the ideals of absentee from the leaders and rulers in the independence war of his population. In the first episode, Ithaca, this whole situation is portrayed from an old woman selling milk. This old woman is a lampoon of the Old lady of the Irish knowledge, who in the moment Ireland wins its independence will be transformed into a beautiful queen. This old woman cannot bring inspiration to the others. Life drying up, the preference for a doctor as Mulligan instead of an intellectual as Stephen and the denying possibility to speak the old Irish language serve to form a literature figure, who has aspired at underestimating the folkloric diggings of many Irish Renaissance writers to assemble the narrations of the Irish in the western part territory. Always contradictive toward such quests to build a fake past as a manner to bypass the present and its consequences, different from other Renaissance writers, Joyce explored the artistic stimuli in Europe.

In all his artistic works, Joyce tries to probe the idea that imperialism is supported by a cosmopolitanism, which plays the role of a disguised European nationalism. Many controversies exist at the core of advanced or Illuminist ideas in the 19th century. They were supposed to be the essence of a changing society, but included many exceptions, starting from the fact that they did not take into consideration the situation of slaves, forbidden beliefs and women. The whole population, out of the European territory, did not subdue such projection of life and human rights. As Robert Young (1990) argues "during the period when colonial invasion was at its highest level of spread, and even more during the dispersion of colonialism, the western philosophers were obliged to face the Eurocentric nature of their intellectual traditions, meanwhile the postcolonial studies followed the same line of thought"(p. 143). Such opposition was becoming prevalent, while the wave of thought against colonialism increased.

Such belief is evident in many episodes of Ulysses, starting from Nestor. In this episode, Stephen does the utmost to wake up of the historical, national and personal anxieties, which are intermixed like a micro cosmos to a macro cosmos, navigating from the history of Greece to that of the modern Ireland. References toward the characters of the Greek history are not at the center of attention in the novel, because they are substituted by updated historical situations, such as the British invasion of Ireland. In the second part of the episode, the author puts at center the character of Deasy, a defender of British politics and an Irish following the British behavior. Taking the role of a philosopher, Deasy defends the idea that every consequence in human history comes from the position of women in it. Through citing three important female names in history such as: Helen of Troy, Devorgilla and Kiti O'Shi, he recalls the political betrayal against Parnell and his followers, but also the betrayal of faith that the Irish had on him. What unites these women, except the historical connotation, is their correlation with Molly Bloom, because they are representatives of different alternatives to female betrayal, who will not be loyal to Bloom. At the end of this part Deasy condemns himself with his arguments.

The quest for justice troubles our characters, and at the same time reflects the actual condition of Ireland, disturbing them in their subconscious. According to Deasy "it seems history is to blame: on me and on my words, unhating" (Joyce, 1961,p.51). In one of the many quarreling episodes between Stephen and Deasy, he says about the English that "But one day you must feel it. We are a generous people but we must also be just" (Joyce, p. 52). But Stephen ironically answers that "I fear those big words, Stephen said, which make us so unhappy" (Joyce, p.52). In the 
following episode, through the stream of consciousness displayed by the technique of interior monologue, Stephen reasons on the truth of things surrounding him. Young male, dreamer, member of a poor family, believer of church teachings, he is transformed into a skeptic Parisian, lost in beliefs. Without the wings of truth, finds himself unprotected from his belief and talent. Part of the many questions is even the state justice articulated with injustice:

Aha. Eating your groatsworth of mou en civet, fleshpots of Egypt, elbowed by belching cabmen. Just say in the most natural tone: When I am in Paris; Boul' Mich', I used to. Yes, used to carry punched tickets to prove an alibi if they arrested you for murder somewhere. Justice. On night of the seventeenth of February 1904 the prisoner was seen by two witnesses. Other fellow did it: other me. Hat, tie, overcoat, nose. Lui, c'est moi. You seem to have enjoyed yourself. (Joyce, p.63)

In the debate related to justice, Bloom includes even himself. In the episode of Cyclopes, the many Cyclopes of the city gather at the pub of Kiernan, build on the ideas of Michael Kuzek, known for the renaissance of old Irish sports to serve his nationalist ideas as e reaction towards the English politics. The satire is directed to the people of the world, who perceive the reality their live from a limited perspective, transforming themselves into the Cyclopes of the modern society. Parallel to the Cyclopes of the Odyssey, those of the 20th century displayed an intellectual blindness. The Cyclopes of the city, represented by the citizen, are portrayed as an Irish pre-historic worrier decorated with tribal images of historic personages as: Goliad, Dante, Captain Memo, Mrs. Godiva, and the Queen of Sheba etc. The ideological clash between Bloom and the citizen is inevitable as a result of a violent, hatred, and revenge environment presented during the whole episode. For the first time in the novel, Bloom exposes his heroism within a modernist approach and the universal anger against the citizen Cyclopes and every nationalist, imperialist ideology based on violence. Through the narration technique of dramatic dialogue, as a consequence of the emotional conditions and the confrontation of personages, is observed their real nature.

And I belong to a race too, says Bloom, that is hated and persecuted. Also now. This very moment. This very instant. Gob, he near burnt his fingers with the butt of his old cigar.

-Robbed, says he. Plundered. Insulted. Persecuted. Taking what belongs to us by right. At this very moment, says he, putting up his fist, sold by auction in Morocco like slaves or cattle.

- Are you talking about the new Jerusalem? says the citizen.

-l'm talking about injustice, says Bloom.

-Right, says John Wyse. Stand up to it then with force like men.

That's an almanac picture for you. Mark for a softnosed bullet. Old lardyface standing up to the business end of a gun. Gob, he'd adorn a sweepingbrush, so he would, if he only had a nurse's apron on him. And then he collapses all of a sudden, twisting around all the opposite, as limp as a wet rag.

-But it's no use, says he. Force, hatred, history, all that. That's not life for men and women, insult and hatred. And everybody knows that it's the very opposite of that that is really life.

-What? says Alf.

-Love, says Bloom (Joyce, p.363)

In the long debate with the European philosophers, the nationalist thoughts expressed from the Illuminists are labeled as obligations towards colonialism. A typical example is the catholic educational system that helped the Irish in their road towards progress and knowledge. In the thoughts of Stephen the whole English literary tradition had the source in this colonial obligation. Interesting within this context is the connection with the philosopher Mathew Arnold (2006, pp.134), cited many times by Stephen in the novel, since he is against the idea that culture through its educational force could be able to put under control dangerous parts of the society by way of anarchy. These ideas, where culture and anarchy cooperate to suppress the voice of the marginalized are contradicted by Stephen. During his whole life Joyce expressed resentment for being obliged to study in College of Dublin University, which he considered inferior to Trinity College. In the episode of Thelemacus, Stephen precisely refers to the student life in that college, through a satiric approach, and even to the threatening usage of education as a manner to invade the mind, spirit and body.

Through the compositional technique of description, while portraying these students he declares:

Young shouts of moneyed voices in Clive Kempthorpe's rooms. Palefaces: they hold their ribs with laughter, one clasping another. O, I shal expire! Break the news to her gently, Aubrey! I shall die! With slit ribbons of his shirt whipping the air he hops and hobbles round the table, with trousers down at heels, chased by Ades of Magdalen with the tailor's shears. $A$ scared calf's face gilded with marmalade. I don't want to be debagged! Don't you play the giddy ox with me ! (Joyce, p.25)

While in some lines beneath he says, "A deaf gardener, approned, masked with Mathew Arnold's face, pushes, his mower on the sombre lawn watching narrowly the dancing motes of grasshalms" (Joyce, p.26). He tries to disparage that 
culture represented by Arnold and the ideology of an empire, which through wide spreading such illusionary ideas avoids the inclusion of colonized voices in its politics. That is the reason why colonialism and nationalism were ingrained in culture, its institutions, the traditions of group individuals and even questioning their aim. For this motive Joyce became a member of the Irish Renaissance at its beginnings, except later abandoning it because its concepts were based on colonialism. He presupposed this movement as an attempt without a real intellectual core, producing known views on the issue of Ireland.

Within this episode we encounter the figure of another personage as Haynes. The first impressions of him are presented by Stephen and Mulligan, who, especially Stephen, expresses the displeasure to live with him under the same house. Haynes is described as a man having all the opportunities of education and living that Stephen did not. Educated in Oxford University and grown up in a healthy family permitted him to live a life enjoying all the amusements of the time. Haynes is described as a typical British imperialist trying to make a study on the Irish folklore, but also showing interest in buying books by different Irish Renaissance authors. He attempts intensively to cite by heart parts of different poetries. Son of an imperialist father, Mulligan says that "His old fellow made his tin by selling jalap to Zulus or some bloody swindle or other" (Joyce, p.25). Every night he involved himself in utopian dreams reviving in the mind the consequences of colonialism accompanied with violence, savagery and the widespread of a controlling culture. The culture of free time was influenced by these ideas in the Zulu territory. The apprehension and anger of Stephen is augmented even more bringing Mulligan to mind the every night experience of an imperialist as Haynes: "I was, Stephen said with energy and growing fear. Out here in the dark with a man I don't know raving and moaning to himself about shooting a black panther. You saved men drowing. I'm not a hero, however. If he stays on here I am off (Joyce, p.22). The apprehension of Stephen resembles that of every Irish against the consequences of the colonial system, resembling a beautiful utopian system, but in deep is based on violence and human rights disrespect.

Even more utopian is the situation described by Haynes. The first time the reader meets Haynes arrives to some impressions alone, without the help of Stephen and Mulligan, especially in understanding that the he sales in utopian waters of the colonial thought. The narration technique used to organise the events is that of a narrator, tempting to uncover them and the personages from within, while presenting the psychological nature of the novel. The involvement of the reader is this context is unavoidable. In the course of a dialogue between Stephen and Haynes, through the technique of dialogue discourse, we understand many things about Haynes.

I am a servant of two masters, Stephen said, an English and an Italian.

-Italian? Haines said.

A crazy queen, old and jealous. Kneel down before me.

-And a third, Stephen said, there is who wants me for odd jobs.

-Italian? Haines said again. What do you mean?

-The imperial British state, Stephen answered, his colour rising, and the holy Roman catholic and apostolic church.

Haines detached from his underlip some fibres of tobacco before he spoke.

-I can quite understand that, he said calmly. An Irishman must think like that, I daresay. We feel in England that we have

treated you rather unfairly. It seems history is to blame. (Joyce, p.40)

It is very evident that Haines does not blame England for the colonisation of Ireland, but the historical consequences. Whereas meeting the milk seller, he attempts to speak Irish, but faces incomprehension on the part of the old seller.

-Do you understand what he says? Stephen asked her.

-Is it French you are talking, sir? the old woman said to Haines.

Haines spoke to her again a longer speech, confidently.

-Irish, Buck Mulligan said. Is there Gaelic on you?

-I thought it was Irish, she said, by the sound of it. Are you from the west, sir?

- I am an Englishman, Haines answered.

-He's English, Buck Mulligan said, and he thinks we ought to speak Irish in Ireland. (Joyce, p.33)

During this ethnographic confrontation, Haynes is exposed as a typical representative of British imperialism and conductor of a cultural utopia. The danger that Haines transmits in this confrontation is not just individual, but the representation of a certain thought and certain regime. This is what frightens Stephen most, Joyce himself and all the Irish community of that period. This is the reason why Joyce is expressed against the Irish Renaissance. 


\section{Conclusions}

The displacement of a culture taking the form of an invading anarchy is widely observed in many episodes of Ulysses. In the first episode, Ithaca, through the literary figures Joyce expresses his contradiction to quests building a fake past as a manner to bypass the present and its consequences, different from other Renaissance writers he explored the artistic stimuli in Europe. In Nestor, Stephen does the utmost to wake up of the historical, national and personal anxieties, which are intermixed like a micro cosmos to a macro cosmos, navigating from the history of Greece to that of the modern Ireland. The author puts at center the character of Deasy, a defender of British politics and an Irish following the British behavior. The ideological clash between Bloom and the citizen is inevitable as a result of a violent, hatred, and revenge environment presented during the whole episode of Cyclopes. For the first time in the novel, Bloom exposes his heroism within a modernist approach and the universal anger against the citizen Cyclopes and every nationalist, imperialist ideology based on violence. Through the narration technique of dramatic dialogue, as a consequence of the emotional conditions and the confrontation of personages, is observed their real nature.

These ideas, where culture and anarchy cooperate to suppress the voice of the marginalized are contradicted by Stephen. During his whole life Joyce expressed resentment for being obliged to study in College of Dublin University, which he considered inferior to Trinity College. In the episode of Thelemacus, Stephen precisely refers to the student life in that college, through a satiric approach, and even to the threatening usage of education as a manner to invade the mind, spirit and body. He tries to disparage that culture represented by Mathew Arnold and the ideology of an empire, which through wide spreading such illusionary ideas avoids the inclusion of colonized voices in its politics. The apprehension of Stephen resembles that of every Irish against the consequences of the colonial system, resembling a beautiful utopian system, but in deep is based on violence and human rights disrespect.

\section{References}

Adorno, Th. \& Horkheimer, M. (1997). Dialectic of Englightment. New York: Verso Books.

Arnold, M. (2006). Culture and Anarchy. Oxford: Oxford University Press.

Beiser, F.C. (1993). The Cambridge Companion to Hegel. Cambridge: Cambridge University Pres.

Comte, A. (2012). Cours de philosophie positive, leçons 46-51. Paris: Hermann.

Crowder, G. (1991). Classical anarchism: the political thought of

Godwin, Proudhon, Bakunin, and Kropotkin. New York: Oxford University Press.

Davis, J.C. (1984). Utopia and the Ideal Society: A Study of Utopian English Writing 1516-1700. Cambridge:Cambridge University Press.

Habermas, J. (1992). The Structural Transformation of the Public Sphere: Inquiry into a Category of Burgeois Society. Cambridge: Polite Press.

Harrison, J. F. C. (1969). Robert Owen and the Owenites in Britain and America. London: Routledge and Kegan Paul.

Karl, M. (1985). Ideology and Utopia: An Introduction to the Sociology of Knowledge. New York: Mariner Books.

Kumar, K. (1987). Utopia and Anti-utopia in Modern Times. Oxford: Blackwell Publishers.

Markham J.(ed.)(1952). Henri Comte de Saint-Simon 1760-1825 Selected Writings. Oxford:Blackwell.

Philip, M. (ed.) (1993). The Political and Philosophical Works of William Godwin, 7 Volumes. Vol.1. London: Pickering and Chatto

Proudhon, P.J. (1840). What is Property: An Inquiry into the Principle of Right and Government. trans. B.R. Tucker, 1994.Cambridge: Cambridge University Press,1994.

Joyce, J. (1961). Ulysses. New York: Random House.

Young, R. (1990). White Mythologies: Writing History and the West. London: Routledge.

Viera, F. \& Freitas M. (2005). Utopian Matters. Theory, Politics, Literature and the Arts. Porto: Universidade de Porto.

Wells, H.G. (2005). A Modern Utopia. New York: Penguin.

Zizek, S. (1989). The Sublime Object of Ideology. New York: Verso. 